\title{
Uji Bioaktivitas Senyawa Glikosida dari Biji Keben (Barringtonia asiatica L. Kurz)
}

\author{
Bustanussalam $^{1 *}$ dan Partomuan Simanjuntak ${ }^{1,2)}$ \\ 1) Pusat Penelitian Bioteknologi-LIPI, Jalan Raya Bogor Km. 46, Cibinong 16911 \\ 2)Fakultas Farmasi, Universitas Pancasila, Srengseng Sawah, Jagakarsa, Jakarta 12640 \\ Diterima 08-04-2009 Disetujui 10-08-2009
}

\begin{abstract}
The fruits or seeds of Keben (Barringtonia asiatica L. Kurz) were used traditionally for fish poisons, to curve stomach and headeach. The aim of this research was to isolate and identify bioactive compound of $n$-butanol fraction of active compound against Artemia salina Leach larvae. Isolation and purification of $\mathbf{n}$-butanol fraction were carried out by column chomatography $\left(\mathrm{SiO}_{2}, \mathrm{CHCl}_{3}-\mathrm{MeOH}\right)$ and high pressure liquid chromatography ( $\mathrm{RP}$, $\mathrm{MeOH}$ ). The result of purification was than tested using BSLT methode. The test showed that, BABU-2.4 had the highest activity with $\mathrm{LC}_{50}$ value was $30.19 \mathrm{ppm}$. BABU-2.4 was identified with FT-IR spectrophotometer and NMR (proton and carbon) spectrophotometer as derivate of glicoside.
\end{abstract}

Keywords: Barringtonia asiatica L. Kurz, glicoside, keben, toxicity

\section{PENDAHULUAN}

Keben (Barringtonia asiatica L. Kurz) termasuk dalam suku Lecythidaceae. Tumbuhan ini banyak dijumpai di sekitar pantai, sepanjang sungai atau di hutan mangrove pada ketinggian $350 \mathrm{~m}$ di atas permukaan laut. Dibeberapa daerah, tumbuhan ini sering disebut sebagai tumbuhan beracun (poisonous plant), karena dibeberapa daerah buahnya digunakan sebagai racun ikan. Misalnya, masyarakat Papua menggunakan biji keben untuk menangkap ikan. Bijinya diparut kemudian disebar dipermukaan selokan yang dalamnya mencapai 1 meter sehingga ikan akan pingsan dan mudah ditangkap dipermukaan air (Lemmes \& Bunyapraphatsara 2003; Samah 1988)

Pemanfaatan tumbuhan ini berbeda-beda di setiap negara dan daerah. Bagian tumbuhan yang digunakan adalah biji, buah dan daunnya. Di Filipina daunnya digunakan sebagai obat untuk sakit perut. Masyarakat Indonesia dan Indo Cina menggunakan buah atau bijinya sebagai racun ikan. Sedangkan suku Aborigin di Australia menggunakan tumbuhan ini sebagai racun ikan dan sebagai obat sakit kepala (Lemmes \& Bunyapraphatsara 2003; Samah 1988; Duryatmo 2006)

Keben mengandung senyawa saponin, terpen, alkaloid, triterpenoid, fenolik dan tanin (Duryatmo 2006). Diduga sebagian besar khasiat obat dalam biji keben

\footnotetext{
*Telp: (021) 8754587, Fax. 8754588

Email: boest77@yahoo.com
}

berasal dari saponin dalam tanaman tersebut. Herlt, (2002), menunjukkan bahwa biji keben mengandung senyawa saponin yang berkhasiat sebagai racun ikan. Herlt juga telah mengisolasi dan menentukan struktur kimianya sebagai $3 \beta, 15 \alpha, 16 \alpha, 22 \alpha, 28 \beta$ pentahydroxyolean-12-ene(1);3 $\beta, 16 \alpha, 22 \alpha, 28 \beta$ pentahydroxyolean-12-ene (2);3-O- $\{[\beta-D$ galactopyranosyl $(1 \rightarrow 3)-\beta$-D-glucopyranosyl $(1 \rightarrow 2)] \beta-D$ glucuronopyranosyloxy\}-22-O-(2-methylbutyroyoxy)$15,16,28$-trihydroxy- $(3 \beta, 15 \alpha, 16 \alpha, 22 \alpha)$-olean-12ene (3);3-O-\{[ $\beta$-D-galactopyranosyl $(1 \rightarrow 3)-\beta-D$ glucopyranosyl $(1 \rightarrow 2)] \beta$-D-glucuronopyranosyloxy\}-22O-[2(E)-methyl-2-butenyloyloxyl-15,16,28-trihydroxy$(3 \beta, 15 \alpha, 16 \alpha, 22 \alpha)$-olean-12-ene (4) (Herlt et al, 2002) (Gambar 1).

Penelitian ini bertujuan untuk mengisolasi dan mengidentifikasi senyawa aktif dari fraksi $n$-butanol berdasarkan hasil pengujian toksisitas terhadap larva udang Artemia salina Leach (Meyer et al., 1982). Diharapkan hasil yang diperoleh dapat digunakan sebagai landasan dalam pemanfaatan keben sebagai obat alami yang memberikan nilai ekonomi tinggi.

\section{BAHAN DAN METODE}

Tempat dan Waktu Penelitian. Penelitian ini dilakukan di Laboratorium Biofarmaka, Pusat Penelitian Bioteknologi-LIPI, Cibinong. Bahan dan Alat Penelitian. Biji keben diperoleh dari Papua dan telah diidentifikasi 


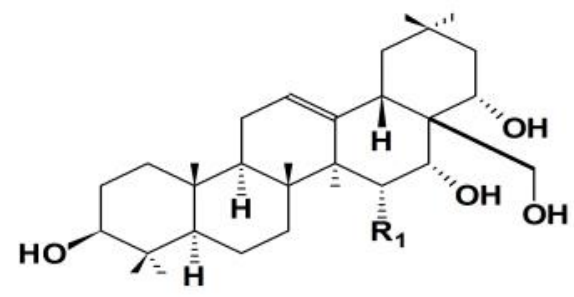

$$
\begin{aligned}
& 1 \mathrm{R}_{1}=\mathrm{OH} \\
& 2 \mathrm{R}_{1}=\mathrm{H}
\end{aligned}
$$

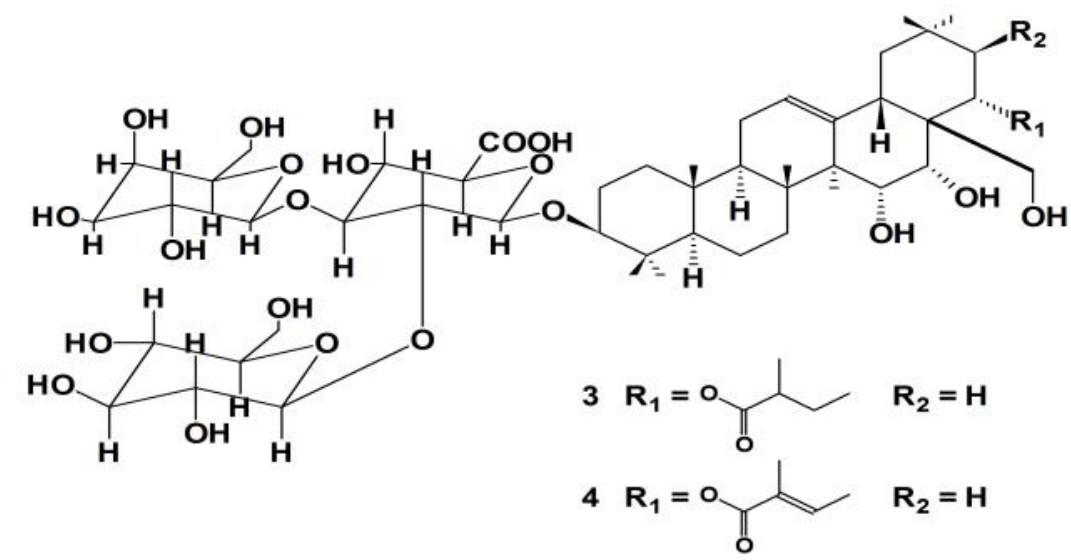

Gambar 1. Struktur senyawa kimia biji keben hasil isolasi Herlt et al., 2002

di Herbarium Bogoriensis (Cibinong) sebagai Barringtonia asiatica (L.) Kurz. Pelarut yang digunakan adalah metanol, etil asetat, $n$-butanol, kloroform, ammoniak, natrium hidroksida. Sedangkan, alat yang kemudian dipartisi kembali dengan $n$-butanol sebanyak 3 kali, dan hasilnya diuapkan dengan penguap berpusing hingga diperoleh ekstrak kasar. Terhadap ketiga ekstrak kemudian dilakukan uji penapisan fitokimia. Untuk menentukan pelarut dalam kromatografi kolom, ekstrak $n$-butanol dianalisis dengan kromatografi lapis tipis (KLT) dengan sistem pelarut kloroformmetanol-air (5:5:1), kloroform-metanol (2:1) dan kloroform-metanol $(1: 1)$.

Analisis Penapisan Fitokimia. Penapisan fitokimia untuk semua ekstrak dilakukan bedasarkan metode Franswort 1996, dimana ekstrak yang akan dianalisis direaksikan dengan pereaksi tertentu dan diamati perubahan warna yang terjadi.

Pengujian Toksisitas dengan Brine Shrimp Lethality Test (BSLT). Pengujian toksisitas dari ekstrak kasar hingga senyawa murni dilakukan berdasarkan metode BSLT (Meyer et al., 1982). Untuk mendapatkan nilai Lethal Concentration (LC), berbagai konsentrasi ekstrak diuji toksisitas terhadap larva, dan setelah 24 jam jumlah larva yang mati dihitung. Semakin kecil nilai $\mathrm{LC}_{50}$, maka semakin besar toksisitasnya .

Fraksinasi ekstrak $n$-butanol dengan Kromatografi Kolom. Fraksi ekstrak $n$-butanol dimurnikan (fraksinasi pertama) dengan kromatografi kolom dengan menggunakan sistem pelarut kloroform-metanol secara gradien dari $5: 1 \sim 1: 1$. Hasil fraksinasi kemudian diuji dengan BSLT untuk melihat fraksi yang aktif. Fraksi yang paling aktif dimurnikan kembali (fraksinasi kedua) dengan kromatografi kolom $\left(\mathrm{SiO}_{2}\right.$, kloroform-metanol = $5: 1 \sim 1: 1)$. Kemudian fraksi-fraksi tersebut diuji kembali dengan BSLT untuk melihat fraksi yang paling aktif. Fraksi yang paling aktif selanjutnya dimurnikan dengan KCKT.

Pemurnian dengan Kromatografi Cair Kinerja Tinggi (KCKT). Fraksi aktif hasil fraksionisasi kedua dimurnikan dengan KCKT dengan kondisi analisis sebagai berikut: fase gerak metanol p.a, fase diam Capcell Pack C-18, kecepatan alir 1,0 mL/menit, panjang gelombang $254 \mathrm{~nm}$ dan volume yang diinjeksikan $20 \mu \mathrm{L}$.

Identifikasi Senyawa Murni. Struktur kimia senyawa murni yang diperoleh ditentukan dengan cara mengambil data spektra spektroskopi infra-merah, untuk mengetahui gugus-gugus fungsi, dan resonansi magnet inti (proton dan karbon), untuk mengetahui jumlah dan karakteristik dari proton dan karbonnya.

\section{HASIL DAN PEMBAHASAN}

Ekstraksi dan partisi. Dari hasil ekstraksi dan partisi 200 gram biji keben diperoleh bobot ekstrak kasar metanol sebanyak 103,41 gram $(51,70 \%)$, etil asetat sebanyak 23,23 gram $(11,62 \%)$, n-butanol sebanyak 17,51 gram $(8,76 \%)$ dan air sebanyak 3,5 
Uji bioaktivitas senyawa glikosida dari biji keben

gram (1,75\%). Rendemen hasil ekstraksi dan partisi biji keben dapat dilihat pada Tabel 1 .

Penapisan Fitokimia. Hasil penapisan fitokimia masing-masing ekstrak ditampilkan pada Tabel 2. Dari tabel tersebut terlihat bahwa ekstrak metanol, etilasetat, $n$-butanol dan air mengandung senyawa triterpenoid; ekstrak metanol, $n$-butanol dan air mengandung senyawa flavonoid dan kuinon; ekstrak metanol dan air mengandung senyawa saponin dan tannin dan ekstrak air mengandung senyawa alkaloid.

Uji Aktivitas dengan Brine Shrimp Lethality Test (BSLT). Hasil uji toksisitas terhadap Artemia salina Leach dapat dilihat pada Tabel 3, 4 dan 5. Dari Tabel 3 terlihat bahwa ekstrak etilasetat dan ekstrak $n$-buatnol memiliki nilai $\mathrm{LC}_{50}$ lebih rendah dari ekstrak air. Ini berarti kedua ekstrak memiliki aktivitas yang lebih tinggi dibandingkan ekstrak air. Atas dasar itu, maka untuk penelitian selanjutnya digunakan ekstrak $n$-butanol.

Tabel 1. Bobot dan rendemen masing-masing ekstrak

\begin{tabular}{llcc}
\hline No & Ekstrak & Bobot (gram) & Rendemen (\%) \\
\hline 1. & Metanol & 103,41 & 51,70 \\
2. & Etil asetat & 23,23 & 11,62 \\
3. & $n$-butanol & 17,51 & 8,76 \\
4. & Air & 3,5 & 1,75 \\
\hline
\end{tabular}

Dari hasil fraksinasi ekstrak $n$-butanol diperoleh 5 fraksi (BABU-1 BABU-5), fraksi BABU-2 memiliki nilai $\mathrm{LC}_{50}$ lebih rendah dari fraksi yang lain. Ini berarti, fraksi tersebut memiliki aktivitas yang lebih aktif dibandingkan fraksi lainnya (Tabel 4). Atas dasar hasil ini, fraksi BABU-2 digunakan untuk fraksinasi selanjutnya.

Dari hasil fraksinasi BABU-2 diperoleh 5 fraksi (BABU-2.1 BABU-2.5). Dari Tabel 5 terlihat bahwa BABU-2.4 memiliki nilai $\mathrm{LC}_{50}$ yang lebih rendah dari fraksi lainnya. Hal ini dapat diartikan bahwa aktivitas fraksi ini paling aktif dibandingkan fraksi-fraksi lainnya.

Tabel 2. Hasil penapisan fitokimia ekstrak biji keben (Barringtonia asiatica L.Kurz)

\begin{tabular}{|c|c|c|c|c|c|}
\hline No & $\begin{array}{l}\text { Penapisan } \\
\text { Fitokimia }\end{array}$ & $\begin{array}{l}\text { Ekstrak } \\
\text { metanol }\end{array}$ & $\begin{array}{c}\text { Ekstrak } \\
\text { Etil } \\
\text { asetat }\end{array}$ & $\begin{array}{c}\text { Ekstrak } \\
n- \\
\text { butanol }\end{array}$ & $\begin{array}{c}\text { Ekstrak } \\
\text { air }\end{array}$ \\
\hline 1. & Alkaloid & - & - & - & + \\
\hline 2. & Flavonoid & + & - & + & + \\
\hline 3. & Saponin & + & - & - & + \\
\hline 4. & Tanin & + & - & - & + \\
\hline 5. & Steroid & - & - & - & - \\
\hline 6. & Triterpenoid & + & + & + & + \\
\hline 7. & Kuinon & + & - & + & + \\
\hline 8. & $\begin{array}{l}\text { Minyak } \\
\text { atsiri }\end{array}$ & - & - & - & - \\
\hline 9. & Kumarin & - & - & - & - \\
\hline
\end{tabular}

Keterangan $=+:$ memberikan hasil positif;

- : memberikan hasil negatif

Tabel 3. Hasil uji toksisitas beberapa ekstrak

\begin{tabular}{|c|c|c|c|c|c|c|c|c|}
\hline Sampel & $\begin{array}{c}\text { Dosis(D) } \\
\text { (bpj) }\end{array}$ & $\log D$ & Mati & Hidup & $\mathrm{M} / \mathrm{T}$ & $\begin{array}{c}\% \\
\text { Kematian }\end{array}$ & Probit & $\begin{array}{l}\mathrm{LC}_{50} \\
(\mathrm{bpj})\end{array}$ \\
\hline \multirow{4}{*}{ Ekstrak etil asetat } & 1000 & 3 & 30 & - & $30 / 30$ & 100,00 & 8,09 & \multirow{3}{*}{31,69} \\
\hline & 100 & 2 & 16 & 14 & $16 / 30$ & 53,33 & 5,08 & \\
\hline & 10 & 1 & 10 & 20 & $10 / 30$ & 33,33 & 4,56 & \\
\hline & 1000 & 3 & 30 & - & $30 / 30$ & 100,00 & 8,09 & \multirow{3}{*}{32,21} \\
\hline \multirow[t]{3}{*}{ Ekstrak $n$-butanol } & 100 & 2 & 18 & 12 & $18 / 30$ & 60,00 & 5,25 & \\
\hline & 10 & 1 & 8 & 22 & $8 / 30$ & 26,67 & 4,39 & \\
\hline & 1000 & 3 & 30 & - & $30 / 30$ & 100,00 & 8,09 & \multirow{3}{*}{39,81} \\
\hline \multirow[t]{2}{*}{ Ekstrak air } & 100 & 2 & 14 & 16 & $14 / 30$ & 46,66 & 4,92 & \\
\hline & 10 & 1 & 7 & 23 & $7 / 30$ & 23,33 & 4,26 & \\
\hline
\end{tabular}

Keterangan : bpj = bagian per sejuta, M/T = mati/total, Probit = analisis statistika

Tabel 4. Hasil uji toksisitas dari hasil fraksionasi pertama

\begin{tabular}{|c|c|c|c|c|c|c|c|c|}
\hline Sampel & $\begin{array}{c}\text { Dosis(D) } \\
\text { (bpj) }\end{array}$ & $\log D$ & Mati & Hidup & $\mathrm{M} / \mathrm{T}$ & $\begin{array}{c}\% \\
\text { Kematian } \\
\end{array}$ & Probit & $\begin{array}{l}\mathrm{LC}_{50} \\
\text { (bpj) }\end{array}$ \\
\hline & 1000 & 3 & 25 & 5 & $25 / 30$ & 83,33 & 5,95 & \\
\hline \multirow[t]{3}{*}{ BABU-1 } & 100 & 2 & 17 & 13 & $17 / 30$ & 56,67 & 5,18 & 70,14 \\
\hline & 10 & 1 & 7 & 23 & $7 / 30$ & 23,33 & 4,25 & \\
\hline & 1000 & 3 & 26 & 4 & $26 / 30$ & 86,67 & 6,13 & \\
\hline \multirow[t]{3}{*}{ BABU-2 } & 100 & 2 & 17 & 13 & $17 / 30$ & 56,67 & 5,18 & 47,97 \\
\hline & 10 & 1 & 9 & 21 & $9 / 30$ & 30,00 & 4,48 & \\
\hline & 1000 & 3 & 24 & 6 & $24 / 30$ & 80,00 & 5,84 & \\
\hline \multirow[t]{3}{*}{ BABU-3 } & 100 & 2 & 16 & 14 & $16 / 30$ & 53,33 & 5,08 & 93,32 \\
\hline & 10 & 1 & 6 & 24 & $6 / 30$ & 20,00 & 4,16 & \\
\hline & 1000 & 3 & 26 & 4 & $26 / 30$ & 86,67 & 6,13 & \\
\hline \multirow[t]{3}{*}{ BABU-4 } & 100 & 2 & 11 & 19 & $11 / 30$ & 36,67 & 4,67 & 95,06 \\
\hline & 10 & 1 & 7 & 23 & $7 / 30$ & 23,33 & 4,26 & \\
\hline & 1000 & 3 & 25 & 5 & $25 / 30$ & 83,33 & 5,95 & \\
\hline \multirow[t]{2}{*}{ BABU-5 } & 100 & 2 & 13 & 17 & $13 / 30$ & 43,33 & 4,82 & 105,9 \\
\hline & 10 & 1 & 6 & 24 & $6 / 30$ & 20,00 & 4,16 & \\
\hline
\end{tabular}

Keterangan $=$ BABU $:$ Barringtonia asiatica $n$-butanol 
Tabel 5. Hasil uji toksisitas dari hasil fraksionasi kedua

\begin{tabular}{|c|c|c|c|c|c|c|c|c|}
\hline Sampel & $\begin{array}{c}\text { Dosis(D) } \\
\text { (bpj) }\end{array}$ & $\log D$ & Mati & Hidup & $\mathrm{M} / \mathrm{T}$ & $\begin{array}{c}\% \\
\text { Kematian }\end{array}$ & Probit & $\begin{array}{l}\mathrm{LC}_{50} \\
\text { (bpj) }\end{array}$ \\
\hline & 1000 & 3 & 30 & - & $30 / 30$ & 100 & 8,09 & \\
\hline \multirow[t]{3}{*}{ BABU-2.1 } & 100 & 2 & 15 & 15 & $15 / 30$ & 50,00 & 5,00 & 35,48 \\
\hline & 10 & 1 & 8 & 22 & $8 / 30$ & 26,67 & 4,39 & \\
\hline & 1000 & 3 & 30 & - & $30 / 30$ & 100 & 8,09 & \\
\hline \multirow[t]{3}{*}{ BABU-2.2 } & 100 & 2 & 17 & 13 & $17 / 30$ & 56,67 & 5,18 & 33,11 \\
\hline & 10 & 1 & 8 & 22 & $8 / 30$ & 26,67 & 4,39 & \\
\hline & 1000 & 3 & 30 & - & $30 / 30$ & 100 & 8,09 & \\
\hline \multirow[t]{3}{*}{ BABU-2.3 } & 100 & 2 & 17 & 13 & $17 / 30$ & 56,67 & 5,18 & 30,90 \\
\hline & 10 & 1 & 9 & 23 & $9 / 30$ & 30,00 & 4,48 & \\
\hline & 1000 & 3 & 30 & - & $30 / 30$ & 100 & 8,09 & \\
\hline \multirow[t]{3}{*}{ BABU-2.4 } & 100 & 2 & 16 & 14 & $16 / 30$ & 53,33 & 5,08 & 30,19 \\
\hline & 10 & 1 & 10 & 20 & $10 / 30$ & 33,33 & 4,56 & \\
\hline & 1000 & 3 & 30 & - & $30 / 30$ & 100 & 8,09 & \\
\hline \multirow[t]{2}{*}{ BABU-2.5 } & 100 & 2 & 14 & 16 & $14 / 30$ & 46,67 & 4,92 & 36,89 \\
\hline & 10 & 1 & 8 & 22 & $8 / 30$ & 26,67 & 4,39 & \\
\hline
\end{tabular}

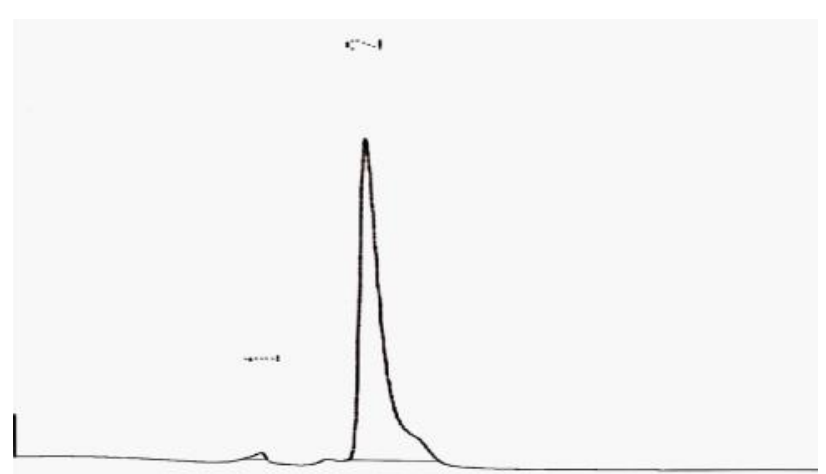

Gambar 2. Kromatogram KCKT fraksi BABU-2.4

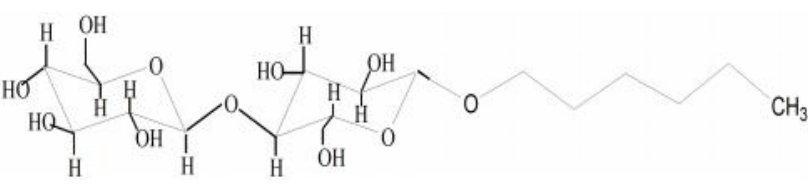

Gambar 3. Perkiraan struktur kimia dari fraksi BABU-2.4

Dari hasil pengujian toksisitas diperoleh bahwa semua ekstrak (etilasetat, $n$-butanol, dan air) dan hasil fraksionasi (BABU-1 BABU-5) dan (BABU-2.1 BABU-2.5) bersifat toksik karena memiliki $\mathrm{LC}_{50}$ kurang dari $1000 \mu \mathrm{g} / \mathrm{ml}$ (Meyer et al., 1982).

Pemurnian Fraksi BABU-2.4 dengan Kromatografi Cair Kinerja Tinggi. Hasil analisis KCKT fraksi BABU2.4 menunjukkan bahwa fraksi tersebut merupakan senyawa murni yang mempunyai RT 5,5 menit. Senyawa tersebut berbentuk kristal amorf berwarna hijau muda. Kromatogram hasil kromatografi cair kinerja tinggi fraksi BABU-2.4 dapat dilihat pada Gambar 2.

Identifikasi senyawa A dengan Infra Merah (IR). Hasil analisis fraksi BABU-2.4 dengan Spektrofotometer FT-IR menunjukkan bahwa terdapat gugus $\mathrm{C}-\mathrm{H}$ alkana pada bilangan gelombang 2873,74 $\mathrm{cm}^{-1}$ dan $2933,53 \mathrm{~cm}^{-1}$; C-O pada bilangan gelombang
Tabel 6. Pergeseran kimia karbon senyawa isolat BABU-2.4 dan jenis gula (Herlt, 2002; Hostettmann \& Marston, 1997)

\begin{tabular}{|c|c|c|c|}
\hline No & $\begin{array}{c}\text { RMI karbon" } \\
\text { Senyawa isolat } \\
\text { BABU } 2.4\end{array}$ & $\begin{array}{l}\text { RMI karbon }^{2)} \\
\text { Senyawa } \\
\text { triterpenglikosida }\end{array}$ & $\begin{array}{c}\text { RMI karbon }^{3} \\
\text { Senyawa } \\
\text { metilglikopiranosida }\end{array}$ \\
\hline & Aglikon & Aglikon & \\
\hline 1 & $14,45(q)$ & Triterpen & \\
\hline 2 & $20,47(\mathrm{t})$ & & \\
\hline 3 & $20,62(t)$ & & \\
\hline 4 & $33,42(t)$ & & \\
\hline 5 & $33,56(t)$ & & \\
\hline \multirow[t]{2}{*}{6} & $61,73(d)$ & & \\
\hline & Gula & Glukosa & \\
\hline 1 ' & 101,71 & 103,8 & 103,7 \\
\hline 2' & 71,64 & 71,8 & 70,3 \\
\hline $3^{\prime}$ & 83,45 & 83,6 & 75,5 \\
\hline $4^{\prime}$ & 70.63 & 72,0 & 73,7 \\
\hline $5^{\prime}$ & 78,44 & 77,7 & 75,5 \\
\hline \multirow[t]{2}{*}{$6^{\prime}$} & 63,52 & 63,1 & 61,7 \\
\hline & & Galaktosa & \\
\hline $1 "$ & 105,23 & 105,2 & 104,1 \\
\hline 2" & 62,27 & 62,9 & 69,1 \\
\hline 3" & 71,02 & 72,1 & 73,3 \\
\hline $4 "$ & 65,11 & 64,9 & 71,2 \\
\hline $5 "$ & 77,36 & 77,2 & 75,3 \\
\hline 6" & 61,98 & 61,9 & 61,4 \\
\hline
\end{tabular}

$1054,03 \mathrm{~cm}^{-1} ; 1162,03 \mathrm{~cm}^{-1}$ dan $1257,5 \mathrm{~cm}^{-1}$; dan O-H pada bilangan gelombang $3348,19 \mathrm{~cm}^{-1}$. Dari data spektra infra merah ini memberikan informasi bahwa struktur kimia mempunyai gugus hidroksil dan $\mathrm{C}-\mathrm{H}$ alkana.

Spektoskopi Resonansi Magnet Inti (RMI) proton dan karbon. Penyidikan spektra untuk senyawa isolat dari fraksi BABU-2.4 dengan RMI proton menunjukkan bahwa $\delta \mathrm{H} 0,93 \sim 1,51$ ppm memberikan informasi adanya - $\mathrm{CH}_{3}$; $-\mathrm{CH}_{2}$ - yang berikatan tunggal, sedangkan $\delta \mathrm{H} 3,31 \sim 4,63$ ppm menunjukkan adanya $\mathrm{CH}-\mathrm{OH}$ dan $-\mathrm{CH}_{2} \mathrm{OH}$ (Gambar 3). Adanya proton anomerik terdapat pada $\delta \mathrm{H} \mathrm{4,18}$ (d) dan 4,11 (d) yang 
Uji bioaktivitas senyawa glikosida dari biji keben

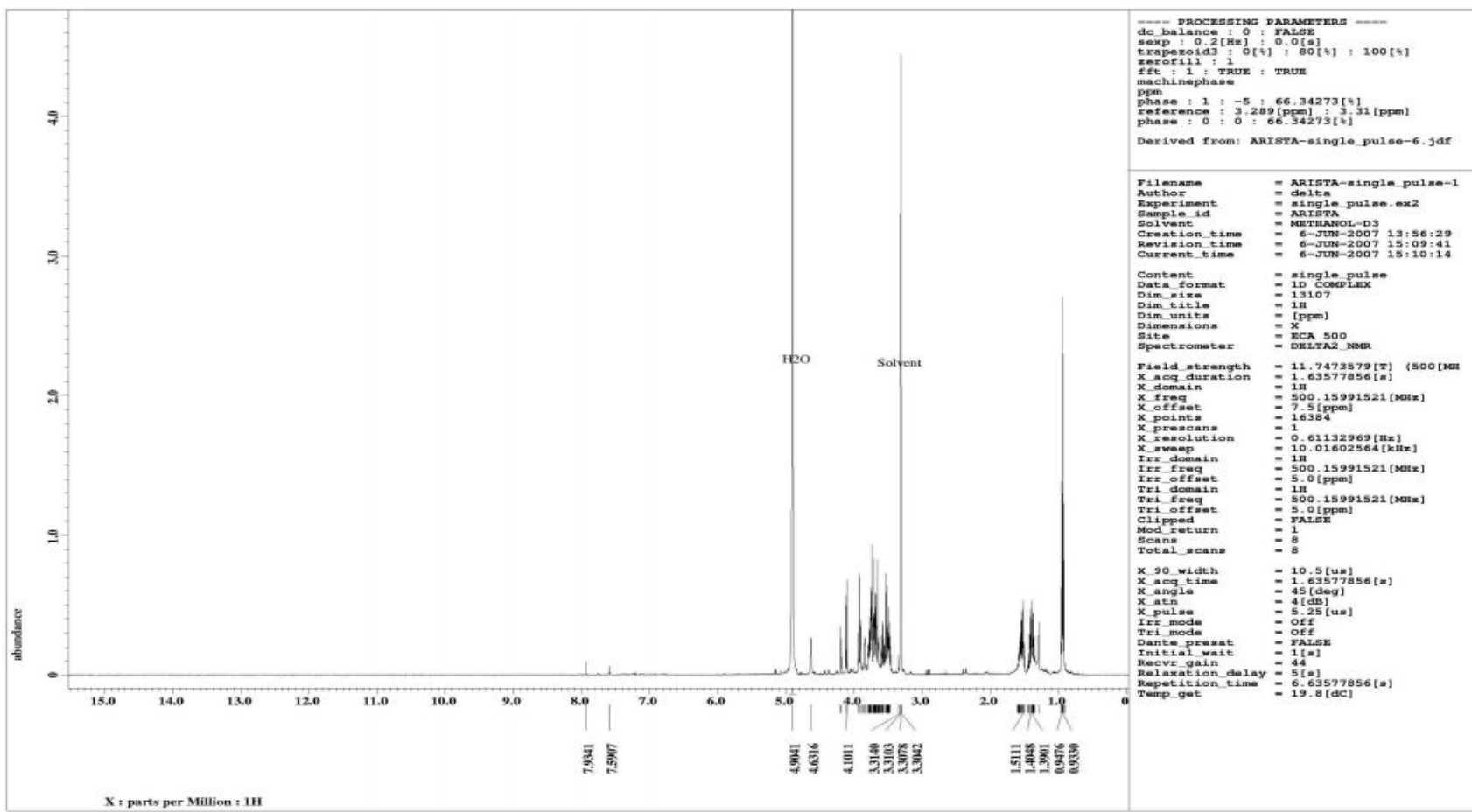

Gambar 4. Spektra RMI proton untuk senyawa isolat BABU-2.4

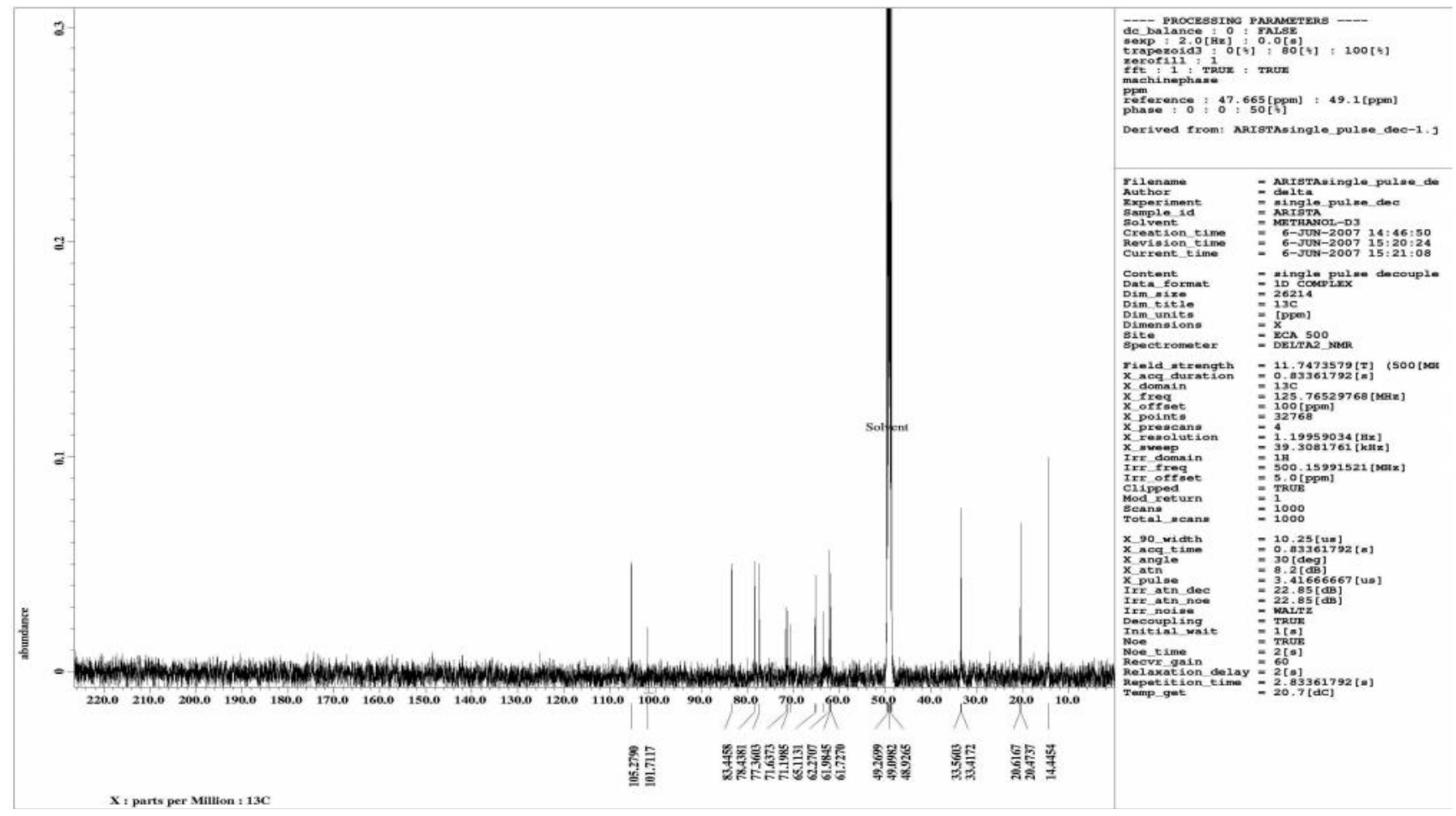

Gambar 5. Spektra RMI karbon untuk senyawa isolat BABU-2.4

menunjukkan bahwa senyawa isolat mempunyai gugus gula (disakarida). Data ini didukung oleh spektra RMI karbon yang terdapat pada $\delta C 101.71$ ppm dan 105,28 ppm yang spesifik untuk karbon glikosidik dari dua monosakarida. Pergeseran kimia karbon lainnya terdapat pada $\delta \mathrm{C} 61,98 \sim 83,45$ ppm yang merupakan jenis karbon teroksigenasi oleh gugus hidroksil (Lihat Tabel 1 dan Gambar 4). Penelusuran pergeseran kimia karbon $(\delta C)$ dari senyawa karbohidrat (sakarida) diperoleh bahwa gula yang terdapat pada senyawa isolat adalah glukosa dan galaktosa. Beberapa perbedaan pergeseran kimia karbon disakarida pada senyawa isolat adalah dikarenakan beda senyawa aglikon yang mengikat gula yaitu triterpen (Herlt, 2002) dan bentuk metil monosakarida (metilglukosa dan metil galaktosa) (Hostettmann \& Marston, 1997) 
Sehingga berdasarkan interpretasi data spektra IR (gugus $\mathrm{OH}$ ), dan RMI proton dan karbon, maka struktur kimia yang diisolasi dari fraksi $n$-butanol Keben (Barringtonia asiatica L. Kurz) diperkirakan senyawa glikosida yang mempunyai asam lemak sebagai aglikonnya.

\section{KESIMPULAN}

Hasil isolasi senyawa kimia dari fraksi $n$-butanol biji keben (Barring

tonia asiatica L. Kuz) adalah suatu senyawa turunan glikosida yang mempunyai daya toksisitas sebesar $\mathrm{LC}_{50}=30,19$ bpj.

\section{UCAPAN TERIMA KASIH}

Terima kasih kepada Arista Fendy Saputro atas asistensinya dan PT. Akar Kehidupan Papua atas kerjasama dalam penelitian ini.

\section{DAFTAR PUSTAKA}

Duryatmo, S. 2006. Obat Papua bermula dari pantai Basege. Majalah Trubus 34: 12.

Franswort, N. R. 1996. Biological and Phytochemical Screenings of Plant. J. Pharm. Sci. 55: 225-265.

Harborne, J. B. 1987. Metode Fitokimia Penuntun Cara Modern Menganalisis Tumbuhan. Bandung: ITB Press.

Herlt, A.J., Mander, L.N., Pongoh, E.J., Rumampuk, R.J., \& Tarigan, P. 2002. Two mayor saponins from seeds of Barringtonia asiatica: putative antifeedants toward Epilachna sp. larvae. J. Nat. Prod. 65: 115-120

Hostettmann K. \& Marston, A. 1997. Saponis, Chemistry and Pharmacology of Natural Products. Cambridge: Cambridge University Press.

Lemmes, R.H.M.J. \& Bunyapraphatsara, N. 2003. Medicinal and poisonous plants. Plant resources of south-east asia, No.12. Bogor: Prosea Foundation.

Meyer, B. N., R. N. Ferrign, J. E. Putnam, L. B. Jacobson, D. E. Nicholas, \& J. L. McLaughlin. 1982. Brine Shrimp: A convenient general bioassay for active plant constituents. Planta Medica 45: 31-34.

Plant profile Barringtonia asiatica L. Kurz. http:// www.plant.usda.gov/java/profile. 30 September 2006

Samah, A. 1988. Study on Barringtonia asiatica Kurz. Buletin Penelitian Kesehatan 16(3): 22

Tanaman Khas di Indonesia. http://www.e-smartschool.com/ PNU/005/PNU0050008.asp. 30 November 2006.

Tan, R. See Poison Tree. http://www.naturia.per.sg/buloh/plants/ sea poison.htm. 30 November 2006. 